\title{
ESTIMASI DURASI, ARAH DAN PANJANG RUPTURE SERTA LOKASI-LOKASI GEMPA SUSULAN MENGGUNAKAN PERHITUNGAN CEPAT
}

\author{
Madlazim \\ Jurusan Fisika, FMIPA Universitas Negeri Surabaya \\ (UNESA) Jl. Ketintang, Surabaya 60231, Indonesia. \\ e-mail: lazim@fisikaunesa.net
}

\begin{abstract}
Abstrak
Telah dilakukan penelitian untuk mengestimasi durasi rupture gempabumi yang terjadi di lautan Hindia (Aceh, Mentawai dan Jawa) yang selama ini dikenal rawan terjadi tsunami yang diakibatkan gempabumi. Kedua, untuk mengestimasi arah rupture dan lokasi-lokasi terjadinya gempa susulan. Estimasi durasi rupture gempabumi dikerjakan dengan menggunakan prosedur langsung, yaitu (1) memfilter seismogram kecepatan komponen vertikal yang direkam oleh jaringan IRIS-DMC dengan menggunakan filter Butterworth pada frekuensi tinggi $(1-5 \mathrm{~Hz})$, (2) melakukan picking waktu kedatangan gelombang $\mathrm{P}$ secara otomatis, (3) menentukan root mean square (RMS) dari amplitudo, (4) mengukur keterlambatan waktu kedatangan gelombang P pada $90 \%$ (T0,9), pada $80 \%$ (T0,8), pada 50\% (T0,5) dan pada 20\% amplitude (T0,2), dan (5) menghitung dan menampilkan hasil perhitungan durasi rupture secara cepat. Berdasarkan hasil analisis dalam riset ini dapat diketahui banwa durasi rupture gempabumi dapat diestimasi secara cepat $( \pm 0,5$ menit setelah gempa bumi terjadi) dan akurat. Selain itu, didapatkan informasi bahwa durasi rupture gempabumi memberikan informasi ekstra, yaitu jika durasi rupture gempabumi lebih besar atau sama dengan 50 detik, gempabumi tersebut berpotensi menimbulkan gempa bumi. Bahkan untuk gempabumi dengan tipe faulting-nya strike-slip bisa berpotensi menimbulkan tsunami jika durasi rupture-nya lebih besar dari 50 detik. Durasi rupture juga memberi informasi tentang arah dan panjang rupture, sehingga lokasi-lokasi yang berpeluang terjadi gempa bumi susulan dapat diestimasi.
\end{abstract}

Kata kunci: Perhitungan cepat, durasi rupture, arah dan panjang rupture, peringatan dini tsunami. 


\section{Latar Belakang}

Peringatan dini tsunami yang efektif untuk gempabumi yang terjadi di dekat garis pantai membutuhkan waktu sekitar 3-10 menit setelah origin time (OT) gempabumi untuk mengumumkan apakah gempa bumi tersebut berpotensi terjadi tsunami atau tidak. Beberapa lembaga seismologi dunia seperti Japan Meteorology Agency (JMA), the Indonesian tsunami early warning system (Ina-TEWS) dan West Coast and Alaska (WCATWC), Pasific (PTWC) Tsunami Warning Centres pertama kali mengidentifikasi gempabumigempabumi yang berpotensi menimbulkan tsunami berdasarkan parameter-parameter gempabumi seperti lokasi, kedalaman dan magnitudo yang ditentukan secara cepat. JMA mengumumkan peringatan dini tsunami untuk masyarakat Jepang sekitar 3 menit setelah OT untuk gempabumi yang menimbulkan tsunami dengan ketinggian 0,5 meter atau lebih. InaTEWS mengumumkan peringatan dini tsunami sekitar 5 menit setelah OT. WCATWC dan PTWC mengeluarkan peringatan dini tsunami sekitar $5-10$ menit setelah OT untuk gempa bumi dangkal yang terjadi di bawah laut Amerika Utara dan Pasifik dengan magnitude $(\mathrm{Mw}) \geq 7,5$ (Hirshorn and Weinstein, 2009).

Data gempabumi telah menunjukkan bahwa walaupun kriteria tersebut sudah terpenuhi, tetapi tidak semua gempa bumi tersebut dapat menimbulkan tsunami. Beberapa gempa bumi dengan magnitudo kurang dari 7 bisa menimbulkan tsunami. Ina-TEWS pernah mengeluarkan peringatan dini tsunami setelah 5 menit setelah OT untuk gempabumi 25 Oktober 2010 yang terjadi di Mentawai, tetapi satu jam kemudian peringatan tersebut dicabut.
Padahal, ratusan warga Kepulauan Mentawai sebenarnya tengah bergelut dengan maut.

Kinerja peringatan dini tsunami perlu terus diperbaiki (Kumar et al., 2010). Perbaikan kinerja antara lain bisa menggunakan parameter selain yang digunakan sebagai indikator potensi tsunami selama ini. Yaitu parameter gempabumi yang telah memiliki pengaruh yang lebih kuat sebagai penyebab terjadinya tsunami. Lomax dan Michelini (2009b; 2011) telah menemukan bahwa parameter panjang rupture dari suatu gempa bumi merupakan parameter yang paling dominan sebagai penyebab tsunami. Dalam seismologi, telah diketahui bahwa panjang rupture sebanding dengan durasi rupture gempa bumi tersebut, sehingga durasi rupture gempa bumi bisa digunakan untuk peringatan dini dari tsunami (Geist dan Yoshioka, 1996; Geist and Parsons, 2005; Olson and Allen, 2005). Dengan menggunakan parameter durasi rupture ini, dalam rentang waktu yang sangat singkat, setelah gempa bumi terjadi, peringatan dini tsunami ini sudah bisa diumumkan. Yang menjadi tantangan adalah bagaimana mengestimasi durasi rupture gempabumi secara cepat dan akurat? Penulis telah berhasil mengestimasi durasi rupture gempabumi secara cepat dan akurat dalam waktu sekitar 0,5 menit setelah seismogram vertical gempabumi tersedia.

\section{Mekanisme Tsunami dan Durasi Rupture}

Tsunami dapat dibangkitkan oleh gempabumi yang terjadi di bawah dasar laut. Tsunami jenis ini paling sering terjadi. Tsunami juga bisa disebabkan oleh letusan gunung api di bawah laut (jarang terjadi), tanah longsor di dasar 
laut (jarang terjadi) dan jatuhnya komet/meteorit besar di laut, belum pernah terjadi, tetapi terjadi dalam sebuah film (Rais, 2006). Pada pembahasan ini dibatasi bahwa tsunami yang terjadi disebabkan oleh gempabumi tektonik.

Energi elastik yang tersimpan di dalam bumi dilepaskan ketika terjadi gempa bumi dan selanjutnya energi ini ditransfer menjadi gelombang tsunami. Gelombang tsunami yang dipicu oleh gempabumi merupakan bahaya ikutan yang dapat menghancurkan dan menghanyutkan bangunan-bangunan di tepi pantai. Dengan demikian, setelah terjadi gempabumi kemudian apakah gempabumi tersebut dapat memicu terjadinya tsunami atau tidak sangat tergantung pada besar energi dan karakteristik dari sumber gempa bumi tersebut. Gambar 1 menunjukkan bahwa tsunami dipicu oleh gempa bumi yang terjadi di dasar laut yang memiliki mekanisme fokal reverse, dimana salah satu blok sesar bergerak ke atas sehingga air terdorong ke atas dengan kecepatan sekitar $800 \mathrm{~km} / \mathrm{jam}$.

Rupture gempa bumi dipengaruhi oleh energi yang dilepaskan oleh sumber gempa bumi tersebut. Dalam teori seismologi, energi yang dilepaskan oleh sumber gempa bumi diilustrasikan sebagai momen seismik $\left(M_{0}\right)$ yang mengakibatkan terbentuknya luas dan rata-rata panjang slip dari rupture. Rupture yang diakibatkan oleh energi sumber gempa bumi tersebut bisa dinyatakan dalam variabel panjang $(L)$, lebar $(W)$ dan jarak slip $(D)$ dari rupture. Hubungan antara $M_{0}$ dengan $L, W$ dan $D$ dinyatakan oleh persamaan:

$M_{o}=G L W D$ dengan parameter $G$ merupakan modulus geser di pusat sumber gempa bumi. Telah ditemukan oleh Lomax dan Michelini (2009b; 2011) bahwa parameter $L$ dari rupture merupakan parameter yang paling dominan pengaruhnya terhadap terjadinya tsunami. Lomax and Michelini (2009b; 2011) juga telah menemukan hubungan antara $L$ dan durasi rupture yang bisa dinyatakan bahwa durasi rupture sebanding dengan panjang rupture. Untuk mengukur panjang rupture diperlukan metode yang komplek dan membutuhkan waktu komputasi yang lebih lama, sehingga tidak layak digunakan untuk peringatan dini tsunami. Sedangkan untuk mengestimasi durasi rupture bisa dilakukan dengan cara menganalisis seismogramseismogram grup gelombang $\mathrm{P}$ yang dominan dari seismogram frekuensi tinggi dari gempa-gempa bumi.

Gelombang seismik $P$ adalah sinyal pertama dari suatu gempa bumi yang diterima oleh stasiun perekam. Pengalaman telah menunjukkan bahwa seismogram frekuensi tinggi (periode < 1 s) mengandung sinyal-sinyal utama dari gelombang $\mathrm{P}$ yang dipancarkan secara langsung dari rupture dengan sedikit interferensi dari gelompang yang terpantul pada permukaan bumi yang disebut fase sP. Dengan demikian, dalam rekaman gelombang $\mathrm{P}$ frekuensi tinggi terdapat sekitar setelah $2-10$ menit setelah even yang memberikan informasi tentang awal sampai akhir dari proses rupture (Lomax and Michelini, 2005). Dengan asumsi bahwa kecepatan rupture suatu gempa bumi besar adalah konstan sepanjang permukaan sesar. Asumsi ini memberi konsekuensi untuk gempa bumi besar kecepatan, rata-rata slip dan lebar rupture sama untuk semua even, sehingga hanya panjang rupture 
(L) saja yang memberi pengaruh yang paling dominan terhadap proses rupture. Panjang rupture ini berhubungan secara langsung dengan parameter durasi rupture dari gelombang $\mathrm{P}$ utama (Tdur). Hubungan ini dapat dinyatakan Tdur sebanding dengan $L / v_{r}$, dengan $v_{r}$ adalah kecepatan rupture yang sebanding dengan kecepatan gelombang S. Dalam penelitian ini, digunakan nilai $v_{s}$ pada kedalaman sekitar $2 \mathrm{~km}$ di bawah permukaan laut adalah 3,1 km/detik (Madlazim et al., 2010a). Sedangkan dalam Seismologi, telah diketahui bahwa $v_{r}$ sebanding dengan $z^{q}(z$ : kedalaman dan $q$ : koefisien yang bernilai positif), sehingga hubungan $L$ dan $z$ bisa menyatakan bahwa Tdur sebanding dengan $L / z^{q}$ ((Lomax and Michelini, 2011). Persamaan ini memberi ilustrasi bahwa Tdur memberi informasi penting tentang $L$ dan $z$, yang terpenting adalah semakin besar Tdur, semakin besar $L$ dan semakin kecil $z$. Dua kondisi ini merupakan karakteristik dari kriteria potensi tsunami.

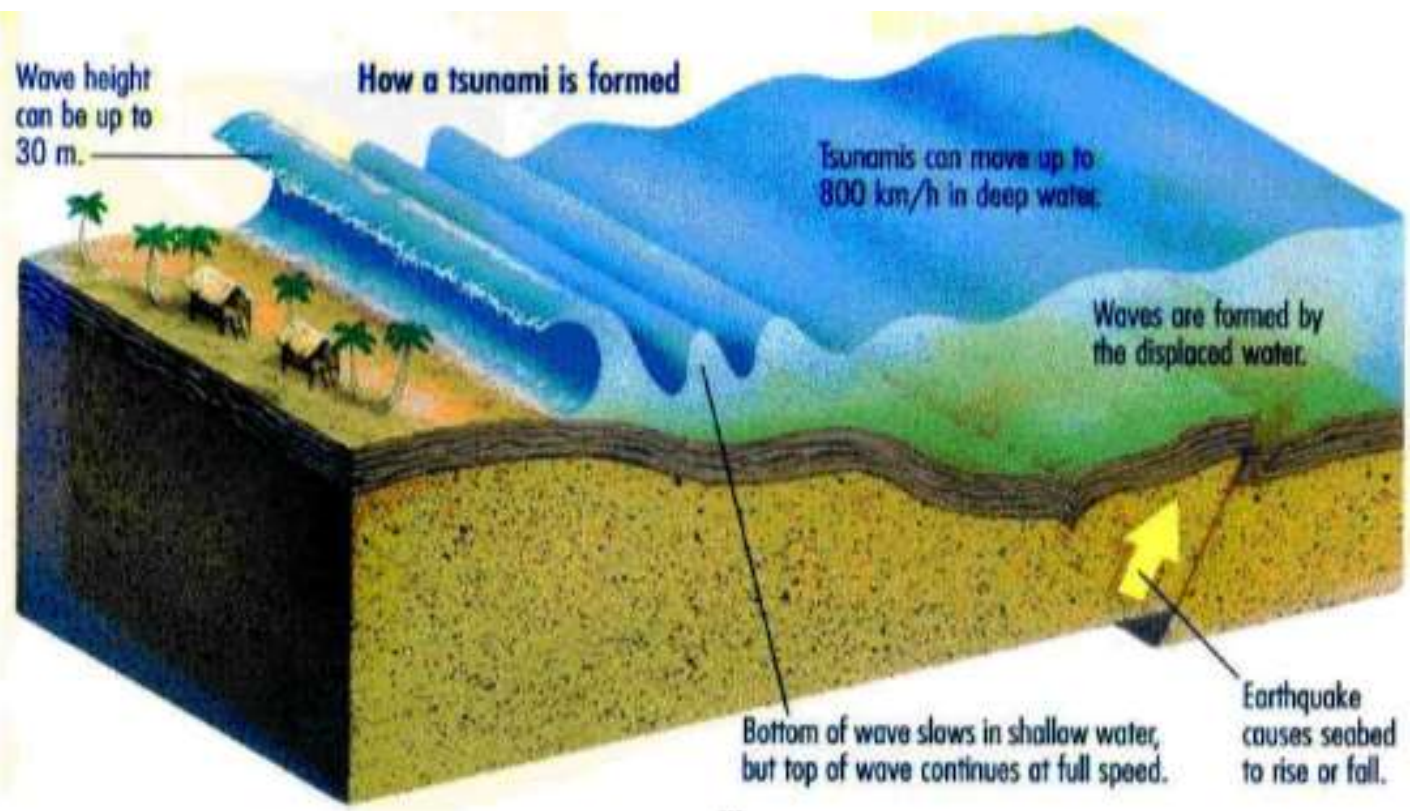

Gambar 1. Mekanisme tsunami yang dipicu oleh gempa bumi (Rais, 2006) .

\section{Metode Estimasi Durasi Ruture}

Seismogram frekuensi tinggi mengandung kelompok gelombang $\mathrm{P}$ yang lebih banyak jumlahnya, sehingga pencarian durasi rupture gempabumi yang diwakili oleh kelompok gelombang $\mathrm{P}$ memenuhi syarat representatif dalam mengestimasi durasi rupture dari suatu gempa bumi (Lomax, A. and Michelini, 2009a).

Algoritma yang digunakan untuk mengestimasi durasi rupture adalah: (1) menyediakan seismogram komponen vertikal dari kecepatan gerakanan tanah dalam format SAC (Goldstein and Snoke, 2005) sebagai raw data; (2) 
menerapkan 4-pole dan filter band-pass Butterworth $1-5 \mathrm{~Hz}$ untuk mendapatkan seismogram rekaman kecepatan pada HF untuk masingmasing stasiun; (3) mengkonversi seismogram HF tersebut menjadi velocity-squared envelopes untuk mendapatkan rms amplitudo; (4) melakukan picking atas arrival time dari gelombang $\mathrm{P}$ secara otomatis pada seismogram HF tersebut; (5) mengukur delay waktu setelah kedatangan gelombang $\mathrm{P}$ untuk $90 \%\left(\mathrm{~T}^{0,9}\right)$, $80 \%\left(\mathrm{~T}^{0,8}\right), 50 \%\left(\mathrm{~T}^{0,5}\right)$ dan $20 \%\left(\mathrm{~T}^{0,2}\right)$ dari nilai puncaknya; dan (6) menghitung durasi rupture, Tdur untuk stasiun tersebut dengan menggunakan persamaan:

Tdur $=(1-w) T^{0,9}+w T^{0,2}$.

dengan,

$$
w=\left[\left(T^{0,8}+T^{0,5}\right) / 2-20\right] / 40 \mathrm{~s}
$$

(3)

dan nilai $w$ dibatasi $0 \leq w \leq 1$ (Lomax \& Michelini, 2009a); (7) plot $T^{0,2}, T^{0,5}$, $T^{0,8}, T^{0,9}$ dan $T d u r$ pada seismogram.
Untuk masing-masing gempabumi, telah digunakan enam sampai 15 stasiun seismik yang merekam seismogram vertikal yang memiliki GCD mulai $2^{\circ}$ hingga $30^{\circ}$ (lokal hingga regional). Algoritma tersebut dipaparkan dalam bentuk diagram alir (Gambar 2).

Algoritma pada gambar 3 diimplementasikan ke dalam software SeisGram2k (Lomax and Michelini, 2009a) untuk mendapatkan seismogram frekuensi tinggi yang menggunakan filter band-pass Butterworth $1-5 \mathrm{~Hz}$, velocity-squared envelopes untuk mendapatkan rms amplitudo, melakukan picking arrival time dari gelombang $\mathrm{P}$ secara otomatis, mendapatkan $\mathrm{T}^{0,9}, \mathrm{~T}^{0,8}$, $\mathrm{T}^{0,5}$ dan $\mathrm{T}^{0,2}$ dari rms amplitudo dan menghitung Tdur.

Seismogram

broad-band komponen vertikal dari kecepatan gerakan tanah (raw data) yang digunakan untuk mengestimasi durasi rupture diunduh dari jaringan kerja IRIS-DMC. Jaringan tersebut masingmasing memiliki stasiun-stasiun seismik yang tersebar di seluruh Indonesia dan dunia 


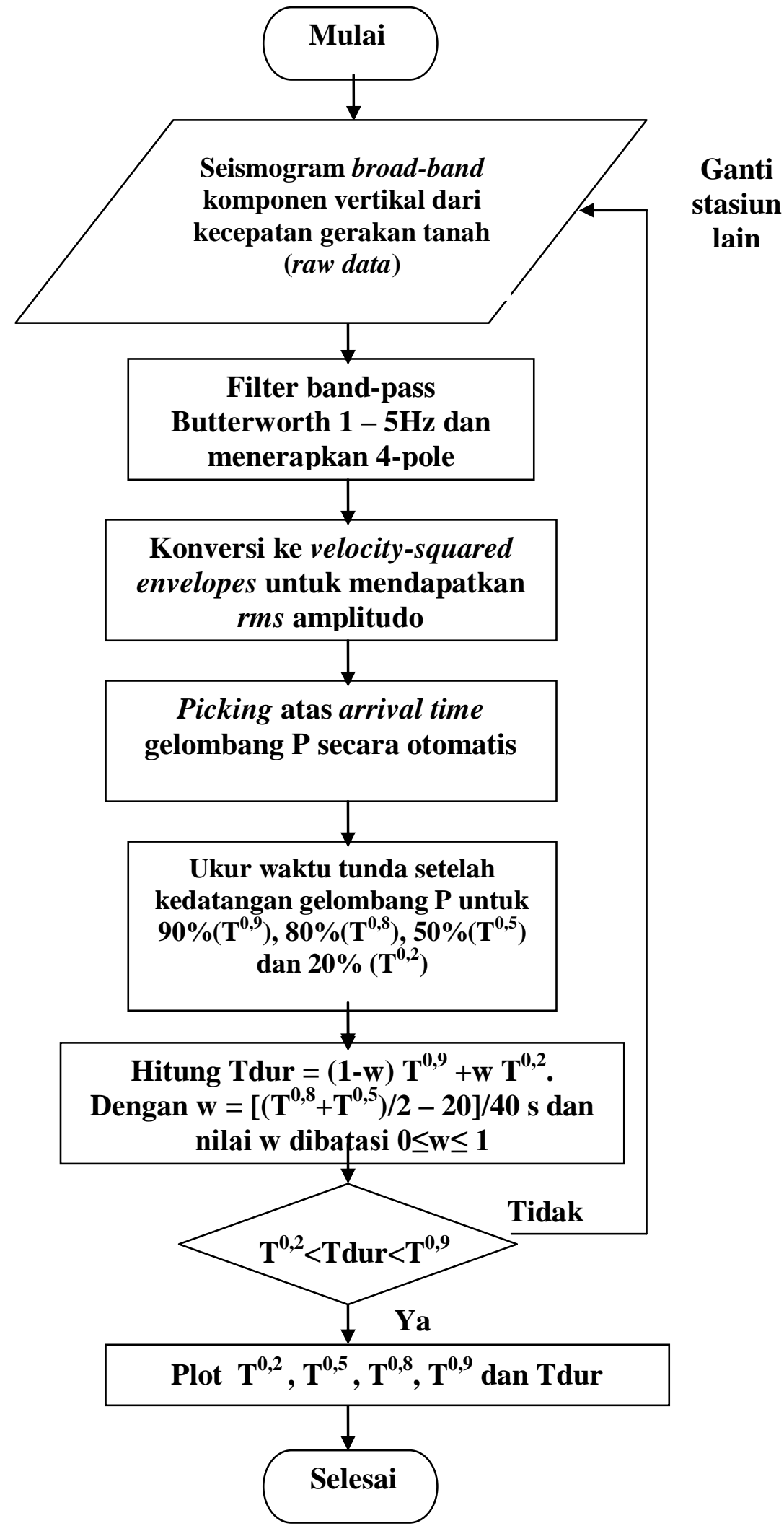

Gambar 2. Bagan alir metodologi estimasi durasi rupture gempa bumi. (Madlazim, 2011a,b) 


\section{Metode Estimasi Arah dan panjang Rupture}

Untuk mengestimasi arah rupture digunakan sinyal periode pendek yang telah direkam oleh dua pasang stasiun. Masing-masing pasangan stasiun berjarak sama atau hampir sama dari episenter, tetapi kedua stasiun berada pada posisi (azimut) yang berlawanan terhadap epiosenter. Kemudian sinyal-sinyal tersebut difilter dengan menggunakan Butterworth frekuensi tinggi, $1-5$ $\mathrm{Hz}$.

Sebagai contoh, untuk mengestimasi arah durasi rupture dari gempa bumi Aceh, 26 Desember 2004 digunakan pasangan stasiun yang berjarak hampir sama dengan episenterbya, yaitu PALK dan COCO serta pasangan ABKT dan WRAB.
Untuk gempa bumi Mentawai menggunakan pasangan stasiun KURK dan TAU serta pasangan MCQ dan KIV. Sedangkan untuk gempa bumi di Jawa menggunakan pasangan stasiun MBAR dan AFI serta pasangan stasiun MSEY dan HNR. Masing-masing pasangan stasiun diestimasi dulu durasi rupture-nya kemudian dibandingkan dengan durasi rupture dari sinyal yang direkan oleh stasiun pasangannya. Bila durasi rupture sinyal yang direkan oleh stasiun lebih kecil dari sinyal yang direkam oleh stasiun pasangannya, maka bisa diinterpretasikan bahwa arah rupture menuju ke stasiun tersebut (http://alomax.free.fr/posters/sasia/ru pture/rupture.html).

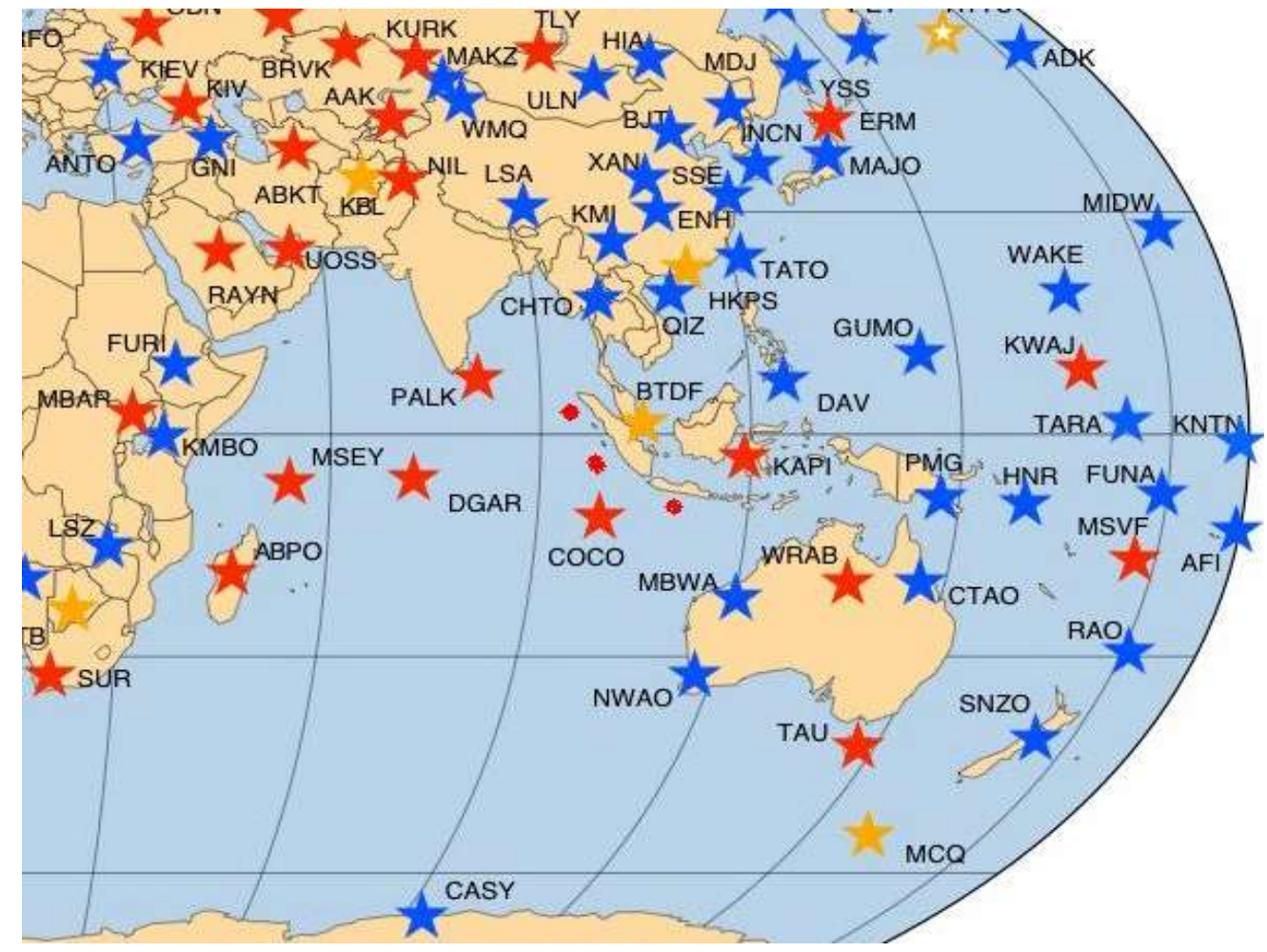

Gambar 3. Distribusi stasiun yang digunakan untuk mengestimasi arah rupture (bintang) dan titik merah adalah episenter gempa bumi Aceh, Mentawai dan Jawa). 


\section{Hasil dan Pembahasan}

.Tabel 1. Hasil estimasi cepat durasi rupture gempa bumi Aceh, 26 Desember 2004

\begin{tabular}{|c|c|c||c|c|}
\hline No. & Nama Stasiun & Jarak $\left({ }^{\circ}\right)$ & Azimuth $\left(^{(}\right)$ & Tdur (s) \\
\hline \hline 1 & ABKT & 48,83 & 319 & 447 \\
\hline \hline 2 & WRAB & 44,20 & 123 & 572 \\
\hline \hline 3 & PALK & 15,71 & $\mathbf{2 8 5}$ & 460 \\
\hline \hline 4 & COCO & 15,41 & 176 & 553 \\
\hline
\end{tabular}

Durasi rupture sinyal dari stasiun ABKT lebih kecil (Tabel 1) dibandingkan sinyal yang direkan oleh stasiun WRAB dan durasi rupture sinyal dari PALK lebih kecil dibandingkan durasi rupture yang direkam oleh COCO. Stasiun ABKT dan PALK berada pada posisi barat laut
(NNW) dari episenter. Sehingga bisa diinterpretasikan bahwa arah rupture mengarah ke barat laut. Hasil ini didukung oleh lokasi-lokasi gempa susulan dari gempa bumi Mentawai tersebut (Gb. 4).

Tabel 2. hasil estimasi cepat durasi rupture gempa bumi Mentawai, 25 Oktober 2010

\begin{tabular}{|c||c||c|c|c|}
\hline No. & Nama Stasiun & Jarak $(\stackrel{\circ}{)})$ & Azimuth $(\stackrel{\circ}{)})$ & Tdur $(\mathbf{s})$ \\
\hline \hline 1 & MCQ & $\mathbf{6 9 , 5 1}$ & $\mathbf{1 4 7}$ & $\mathbf{1 9 3}$ \\
\hline \hline 2 & KIV & $\mathbf{6 9 , 7 2}$ & $\mathbf{3 1 9}$ & $\mathbf{9 4}$ \\
\hline \hline 3 & KURK & $\mathbf{5 7 , 0 5}$ & $\mathbf{3 4 3}$ & $\mathbf{1 2 0}$ \\
\hline \hline 4 & TAU & $\mathbf{5 7 , 3 9}$ & $\mathbf{1 4 0}$ & $\mathbf{1 3 9}$ \\
\hline
\end{tabular}

Dua stasiun yang berada pada posisi di sebelah barat laut dari episenter gempa bumi Mentawai (KIV dan KURK) merekam sinyal yang durasi rupturenya lebih kecil (Tabel 2) dibandingkan sinyal yang direkam oleh pasangannya masing-masing (MCQ dan TAU). Maka dapat disimpulkan bahwa arah rupture dari gempa bumi Mentawai ke Barat Laut (NNW).
Dua stasiun yang berada pada posisi di sebelah Timur dari episenter (HNR dan AFI) merekam sinyal yang durasi rupture-nya lebih kecil (Tabel 3) dibandingkan dengan sinyal yang direkam oleh pasangannya masingmasing (MSEY dan MBAR). Maka dapat disimpulkan bahwa arah rupture dari gempa bumi Jawa tersebut ke arah Timur. 
Tabel 3. hasil estimasi cepat durasi rupture gempa bumi Jawa, 17 Juli 2006

\begin{tabular}{|c|c|c|c|c|}
\hline No. & Nama Stasiun & Jarak $\left(^{(}\right)$ & Azimuth $\left(^{\circ}\right)$ & Tdur (s) \\
\hline 1 & MSEY & 51,71 & 271 & 242 \\
\hline 2 & HNR & 51,80 & 94 & 168 \\
\hline$\overline{\bar{z}}$ & MBAR & 76,75 & 271 & 181 \\
\hline 4 & AFI & 78,98 & 102 & 127 \\
\hline
\end{tabular}

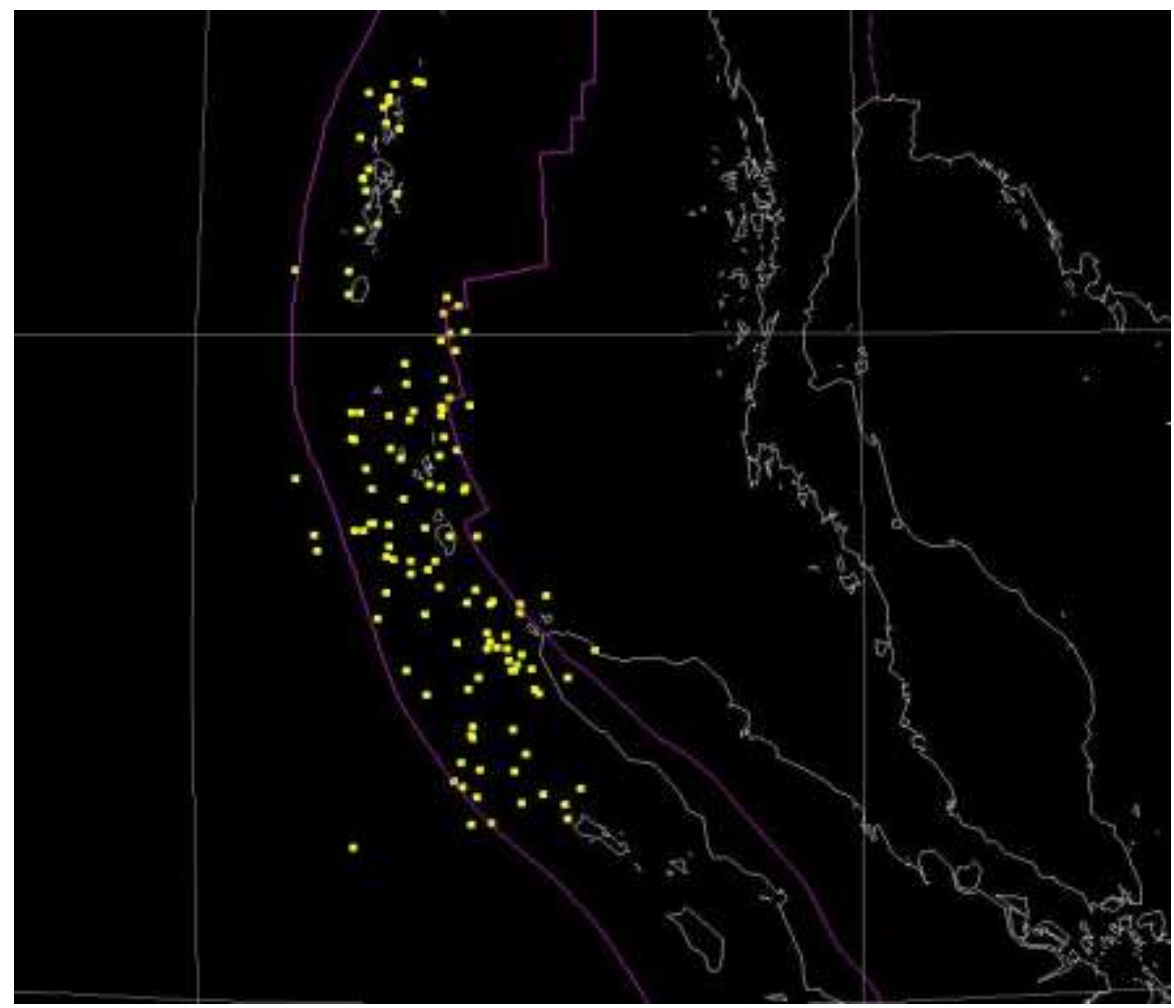

Gambar 4. Lokasi gempa susulan (kuning) dari gempa utama do Aceh, 26 Desember 2004.

\section{Kesimpulan}

Durasi rupture memberikan informasi lebih terhadap informasi peluang terjadinya tsunami. Jika gempabumi terjadi dengan durasi rupture lebih besar dari 50 detik, maka gempa bumi tersebut berpotensi menimbulkan tsunami. Semakin lama durasi rupture suatu gempabumi, maka berarti gempabumi tersebut semakin panjang rupture-nya. Durasi rupture juga memberi informasi tentang arah dan panjang rupture, sehingga lokasi-lokasi yang berpotensi terjadi gempa bumi susulan dapat diestimasi secara lebih cepat dan bisa segera diumumkan kepada masyarakat.

\section{Ucapan Terima Kasih}

Terima kasih kepada IRIS DMC (http://ww.iris.edu) yang telah menyediakan akses seismogram yang 
digunakan dalam penelitian ini. Lebih lanjut, saya juga berterima kasih kepada Anthony Lomax yang telah memberi pemahaman dan bimbingan perhitungan durasi rupture secara cepat dengan menggunakan software SeisGram2k (http://alomax.free.fr/software.html).

\section{Referensi}

1. Aydan, O., 2008. Seismic and tsunami hazard potential in Indonesia with a spatcial emphasis on Sumatra island, Journal of The School of Marine Science ans Technology, Tokai University, 6 (3), 19-38.

2. Madlazim, Bagus Jaya Santosa, Jonathan M. Lees and Widya Utama, 2010. Earthquake Source Parameters at Sumatran Fault Zone: Identification of the Activated Fault Plane, Cent. Eur. $\mathrm{J}$

Geosci.,2(4),2010.DOI:10.2478/ v10085-010-0016-5.

3. Madlazim, 2011a. CMT, Fault Plane and Rupture Duration for Earthquakes in Sumatra and Possibility of its Implementation for Tsunami Early Warning System, PhD Program of Technology Sepuluh Nopember Institute (ITS) Surabaya.

Dissertation.

4. Madlazim, 2011b. TOWARD INDONESIAN TSUNAMI

EARLY WARNING SYSTEM BY USING RAPID RUPTURE DURATIONS CALCULATION, INTERNATIONAL JOURNAL SCIENCE OF TSUNAMI HAZARDS, 4(30).
5. Baeda, A. Y., 2011. Seismic and Tsunami Hazard Potential in Sulawesi Island, Indonesia, Journal of International Development and Cooperation, Vol. 17, No. 1, 2011, pp. 17-30.

6. Brune, S., Babeyko, A.Y., Ladage, S., and Sobolev, S. V., 2010. Landslide tsunami hazard in the Indonesian Sunda Arc, Nat. Hazards Earth Syst. Sci., 10, 589-604.

7. Kruger, F. and Ohrnberger, M., 2005. Tracking the rupture of the Mw 9.3 Sumatra earthquake over $1150 \mathrm{~km}$ at teleseismic distance, Nature, 435, 937-939, doi:10.1038/nature03696.

8. Lay, T., Kanamori, H., Ammon, C. J., Nettles, M., Ward, S. N., Aster, R. C., Beck, S. L., Bilek, S. L., Brudzinski, M. R., Butler, R., DeShon, H. R., Ekstrom, G., Satake, K. and Sipkin, S., 2005. The great Sumatra- Andaman earthquake of 26 December 2004, Science, 308, 1127-1133.

9. Ishii, M., Shearer, P. M., Houston, H., and Vidale, J. E., 2005. Extent, duration and speed of the 2004 Sumatra-Andaman earthquake imaged by the Hi-Net array, Nature, 435, 933-936, 2005.

10. Irsyam, M., Sengara, W., Aldiamar, F., Widiyantoro, S., Triyoso, W., Hilman, D., Kertapati, E., Meilano, I., Suhardjono, Asrurifak, M. Ridwan, M., 2010. Ringkasan Hasil Studi Tim Revisi Peta Gempa Indonesia 2010, Bandung.

11. Pribadi, S., 2008. Indonesia Tsunami Early Warning System for 
Disaster Mitigation,

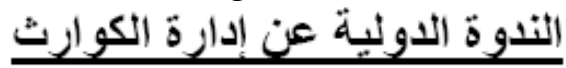

12. Lomax, A., Michelini, A. \& Piatanesi, A., 2007. An energyduration procedure for rapid determination of earthquake magnitude and tsunamigenic potential, Geophys. J. Int., 170, 1195-1209, doi:10.1111/j.1365246X.2007.03469.x.

13. Lomax, A. \& Michelini, A., 2009a. Mwpd: a duration-amplitude procedure for rapid determination of earthquake magnitude and tsunamigenic potential from $\mathrm{P}$ waveforms, Geophys. J. Int., 176, 200-214, doi:10.1111/j.1365246X.2008.03974.x.

14. Lomax, A. \& Michelini, A., 2009b. Tsunami early warning using earthquake rupture duration, Geophys. Res. Lett., 36, L09306, doi:10.1029/2009GL037223.

15. Lomax, A. and A. Michelini, 2011. Tsunami early warning using earthquake rupture duration and P-wve dominant period: the importance of length and depth of faulting, Geophys. J. Int. 185, 283-291, doi: 10.1111/j.1365246X.2010.04916.x.

16. Hara,T., 2007. Measurement of the duration of high-frequency energy radiation and its application to determination of the magnitudes of large shallow earthquakes, Earth Planets Space, 59, 227-231.

17. Okal, E.A., 1988. Seismic parameters controlling far-field tsunami amplitudes: a review, Nat. Hazards, 1, 67-96.

18. Geist, E. and Yoshioka, S., 1996. Source Parameters Controlling the Generation and Propagation of Potential Local Tsunamis, NaturalHazards 13: 151-177.

19. Gomez, J.M., Madariaga, R., Walpersdorf, A., and Chalard, E., 2000. The 1996 Earthquakes in Sulawesi, Indonesia, Bull. Seism. Soc. Am., 90, 3, pp. 739-751.

20. Bilek, S. L. and Lay, T., 1999. Rigidity variations with depth along interplate megathrust faults in subduction zones, NATURE, Vol. 400, 29 July 1999, www.nature.com.

21. Geist, E.L. \& Bilek, S.L., 2001. Effect of depth-dependent shear modulus on tsunami generation along subduction zones, Geophys. Res. Lett., 28, 13151318 , doi:10.1029/2000GL012385.

22. Nakamura, Y., 1988. On the urgent earthquake detection and alarm system (UrEDAS), in Proc. of the 9th World Conference on Earthquake Engineering, TokyoKyoto, Japan. 